\title{
MOTIVASI MENGAJAR GURU DITINJAU DARI KEPUASAN KEBUTUHAN BERDASAR DETERMINASI DIRI
}

\author{
Hanggara Budi Utomo ${ }^{1,2}$, Dewi Retno Suminar ${ }^{2}$, Hamidah $^{2}$, Dema Yulianto ${ }^{1}$ \\ ${ }^{1}$ Fakultas Keguruan dan Ilmu Pendidikan, Universitas Nusantara PGRI Kediri \\ J1. KH. Achmad Dahlan 76, Kediri, 64112 \\ ${ }^{2}$ Program Doktoral Psikologi, Universitas Airlangga \\ Jl. Airlangga 4-6, Kampus B Unair, Surabaya, Indonesia, 60286
}

hanggaram.psi@gmail.com

\begin{abstract}
This study specifically aims to analyze the contribution of need satisfaction for autonomy, need satisfaction for competence, and need satisfaction for relatedness that is associated with teacher teaching motivation. The participants of this study were 84 early childhood education programs teachers in Kediri Regency and Tulungagung Regency $\left(100 \%\right.$ women, $M_{\mathrm{age}}=31.71$ years; $\left.S D=8.86\right)$. Data were collected using the Basic Need Satisfaction in General Scale and the Autonomous Motivation for Teaching Questionnaire presented in Indonesian language. Data analysis in this study used descriptive statistical techniques and Pearson correlation technique. The results shows that there is no significant correlation between need satisfaction for autonomy with teaching motivation $(r=.043 ; p=.585)$, there is significant correlation between need satisfaction for relatedness with teaching motivation $(r=.208 ; p=.008)$, and there is significant correlation between need satisfaction for competence with teaching motivation $(r=.167 ; p=.031)$. Understanding teaching motivation based on selfdetermination may help teachers in disadvantaged areas to improve and recognize self-potential, so that teachers can develop themselves by optimizing need satisfaction as a factor that influences the teacher's activities in teaching.
\end{abstract}

Keywords: teaching motivation; need satisfaction; teachers

\begin{abstract}
Abstrak
Penelitian ini secara khusus bertujuan untuk menganalisis kontribusi kepuasan kebutuhan untuk mandiri, kepuasan kebutuhan untuk kompeten, dan kepuasan kebutuhan untuk terhubung dengan orang lain yang dikaitkan dengan motivasi mengajar guru. Partisipan penelitian ini adalah guru Pendidikan Anak Usia Dini (PAUD) di Kabupaten Kediri dan Kabupaten Tulungagung berjumlah 84 orang (100\% perempuan; $M_{\mathrm{usia}}=$ 31,71 tahun; $S D=8,86$ ). Data dikumpulkan menggunakan skala Basic Need Satisfaction in General dan Kuesioner Autonomous Motivation for Teaching yang disajikan dalam Bahasa Indonesia. Analisis data dalam penelitian ini menggunakan teknik statistik deskriptif dan teknik korelasi Pearson. Hasil perhitungan kepuasan kebutuhan untuk mandiri dengan motivasi mengajar menunjukkan hasil yang tidak signifikan $(r=0,043 ; p=$ 0,585). Hasil perhitungan kepuasan kebutuhan untuk terhubung dengan orang lain dengan motivasi mengajar menunjukkan hasil yang signifikan $(r=0,208 ; p=0,008)$. Hasil perhitungan kepuasan kebutuhan untuk kompeten dengan motivasi mengajar menunjukkan hasil yang signifikan $(r=0,208 ; p=0,031)$. Pemahaman akan motivasi mengajar berdasar determinasi diri, diharapkan dapat membantu guru di daerah terpencil untuk meningkatkan dan mengenal potensi diri, sehingga guru dapat mengembangkan diri dengan mengoptimalkan kepuasan kebutuhan sebagai faktor yang berpengaruh pada aktivitas guru dalam mengajar.
\end{abstract}

Kata kunci: motivasi mengajar; kepuasan kebutuhan; guru

\section{PENDAHULUAN}

Pendidikan di Indonesia saat ini masih belum merata dan kualitasnya masih jauh dari negara lain. Kualitas pendidikan di Indonesia menurut Baswedan (2014) menempati peringkat ke-64 dari 65 negara berdasarkan data dari lembaga Programme for International Study Assessment (PISA). Data dari lembaga The Learning Curve, Indonesia berada pada peringkat 40 dari 40 negara pada pemerataan kualitas pendidikan (Baswedan, 2014). 
Berdasarkan data Dapodik dan Simarsio tahun 2015, kebutuhan guru untuk jenjang pendidikan dasar sebanyak 492.765 guru di 34 provinsi (Tim Litbang, 2016). Namun, berdasarkan laporan dari tingkat sekolah, kabupaten atau kota, dan provinsi di seluruh Indonesia yang masuk dalam data pokok pendidikan, terdapat kelebihan guru sebanyak 143.729 guru (Tim Litbang, 2016). Kondisi tersebut hanya terjadi di daerah perkotaan saja, sedangkan di daerah dengan status perkembangan tertinggal atau terpencil masih kekurangan guru.

Propinsi Jawa Timur sangat gencar memprogramkan pengembangan Pendidikan Anak Usia Dini (PAUD) melalui Dinas Pendidikan, khususnya yang menjadi prioritas di seluruh daerah terpencil. Berdasarkan data satuan pendidikan sekolah anak usia dini Kementrian Pendidikan dan Kebudayaan, bahwa di Jawa Timur terdapat 43.776 lembaga PAUD (Kemdikbud, 2016). Hal ini dapat dilihat dari distribusi lembaga yang masih belum merata diseluruh wilayah Kabupaten Tulungagung. Selain itu, di wilayah Kabupaten Kediri terdapat 1.564 lembaga PAUD yang sudah terdaftar, namun senyatanya masih belum bisa menjangkau semua sasaran yang ada (Direktorat Pembinaan PAUD, 2012). Berdasarkan Keputusan Menteri Desa, Pembangunan Daerah Tertinggal, dan Transmigrasi Republik Indonesia Nomor 126 Tahun 2017 tentang penetapan desa prioritas sasaran pembangunan desa, pembangunan daerah tertinggal, dan transmigrasi, bahwa terdapat daerah dengan status perkembangan terpencil/tertinggal di Kabupaten Tulungagung dan Kabupaten Kediri (Ditjen PDT, 2016). Misalnya, yang terjadi di PAUD PKK Desa Kalipang Kabupaten Kediri bahwa dari segi sarana media pembelajaran yang dimiliki kurang memadai, kondisi masyarakat yang mengajak anaknya ikut ke sawah karena pemahaman orang tua terhadap pendidikan sangat kurang, sehingga guru memiliki inisiatif mensosialisasikan pentingnya pendidikan untuk anak secara door to door. Prasarana gedung sekolah masih meminjam milik warga, bahkan untuk menjangkau lokasi sekolah, harus melewati jalan berliku dengan beberapa tanjakan.

Berdasarkan informasi tersebut, bahwa guru yang mengajar di daerah terpencil menggambarkan perbedaan kendala yang dihadapi. Guru di daerah terpencil dihadapkan pada tantangan alam, karakteristik masyarakat, sosial budaya serta perbedaan agama yang merupakan hambatan dalam mengemban tugas mulia ini. Selain itu, akses mendapatkan layanan informasi serba terbatas dibandingkan dengan keberadaan guru diperkotaan, dan masalah yang dihadapi guru di perkotaan tidak sekompleks dan serumit dengan guru di desa tertinggal (Kadir, 2015).

Hasil penelitian Berg (dalam Paramitha, 2012) alasan guru enggan mengajar di daerah terpencil adalah tidak adanya fasilitas yang memadai, sarana dan prasarana yang minim untuk menunjang proses belajar, ketersediaan tempat tinggal guru yang tidak dipenuhi oleh pemerintah, dan tuntutan mengajar guru di daerah terpencil lebih berat daripada guru di perkotaan. Akibatnya banyak guru yang sebelumnya berada di desa tertinggal atau terpencil merasa tidak nyaman, dan mengajukan pindah sekolah di perkotaan (Paramitha, 2012). Oleh karena itu, dalam menjalankan tugas dan tanggung jawab sebagai guru, khususnya guru yang mengajar di pedesaan diperlukan motivasi dari dalam individu yang kuat.

Tanpa adanya motivasi dari dalam individu yang kuat, mengajar bisa menjadi hal yang berat dan bahkan dapat memunculkan hal-hal yang negatif pada diri guru. Hal ini sesuai dengan penelitian Ryan dan Deci (2009) yang menjelaskan bahwa motivasi yang ditentukan sendiri oleh guru dalam mengajar dapat menghasilkan berbagai hal yang positif, dan mengajar juga membutuhkan pengetahuan dan keahlian serta keterampilan yang luas sehingga pengalaman keahlian mengajar berperan penting bagi motivasi seorang guru (Snowman, McCown, \& Biehler, 2012). 
Peneliti dan praktisi telah mengabdikan cukup banyak energi untuk memahami motivasi guru. Penelitian Jesus dan Lens (2005) menunujukkan bahwa guru tingkat dasar dan guru SMA memiliki motivasi yang rendah di tempat kerja. Guru menunjukkan tingkat motivasi yang lebih rendah dan tingkat stres yang lebih tinggi dibandingkan kelompok profesional lainnya. Senada dengan penelitian Howard dan Johnshon (2004) yang mengulas tentang stres pada guru bahwa stres pada guru dapat timbul dari lingkungan kerja yang buruk dan tidak mendukung proses belajar mengajar, misalnya minimnya sarana prasarana dan isolasi geografis. Namun, di sisi lain, Levesque, Blais, dan Hess, (2004) menyatakan motivasi guru penting untuk fungsi individu yang optimal di tempat kerja karena guru yang bermotivasi tinggi lebih terlibat dalam pekerjaan dan kepuasan kerja.

Penelitian sebelumnya tentang motivasi guru telah banyak dilakukan dan dikaitkan dengan faktor yang mempengaruhi: faktor identifikasi, (Carson \& Chase, 2009); faktor klasifikasi motivasi, (Dinham \& Scott, 2000; Sinclair, 2008); factor demotivasi dan motivasi siswa, (Kiziltepe, 2008; Sugino, 2010), keefektifan mengajar guru: pengajaran dan praktik pembelajaran, (Retelsdorf \& Gunther, 2011); pendekatan mengajar guru, (Han, Yin, \& Wang, 2015, 2016); gaya mengajar, (Hein, dkk, 2012), dan praktek pengajaran, (Thoonen, dkk, 2011), strategi memotivasi siswa (Bernaus \& Gardner, 2008; Bernaus, Wilson, \& Gardner, 2009).

Sementara itu, penelitian motivasi mengajar guru menggunakan perspektif teori determinasi diri belum banyak dilakukan, meskipun Hamidi, Endang, dan Chiar (2015) menyatakan bahwa terdapat faktor intrinsik guru bertahan mengajar di daerah pedalaman atau tertinggal. Namun, pada saat yang bersamaan juga, tidak semua aktivitas atau perilaku termotivasi secara instrinsik. Misalnya, di lingkungan sekolah terdapat struktur, kontrol, dan juga penghargaan yang sifatnya ekstrinsik, yang mungkin tidak sesuai dengan motivasi instrinsik (Deci \& Ryan, 2002).

Motivasi dengan teori determinasi diri merupakan hal yang sangat penting bagi perkembangan individu, karena guru yang termotivasi secara intrinsik dalam lingkungan kerja seperti mengajar dapat meningkatkan berbagai hasil positif (Ryan \& Deci, 2000b). Misalnya, guru termotivasi secara intrinsik atau memiliki motivasi determinasi diri lebih mungkin untuk meningkatkan usaha, keterlibatan dalam kegiatan sekolah dan belajar (Black \& Deci, 2000; Shen, McCaughtry, Martin \& Fahlman, 2009). Hasil penelitian Shen, McCaughtry, Martin dan Fahlman, (2009) menyatakan bahwa pendekatan mengajar guru dengan memberikan kesempatan pada siswa untuk terlibat secara aktif dapat meningkatkan kualitas pembelajaran. Senada yang disampaikan Black dan Deci (2000) menyatakan bahwa dukungan otonomi guru dalam bentuk motivasi menentukan keefektifan siswa dalam belajar.

Gaya memotivasi seorang guru terhadap siswa berkisar pada apa yang guru katakan dan lakukan untuk memotivasi siswa agar terlibat dalam kegiatan belajar, dan memanifestasikan dirinya dalam hal dukungan otonomi terhadap pengendalian mengajar (Gagne \& Deci, 2014). Disamping itu, Bieg, Backes, dan Mittag (2011) juga menyatakan bahwa guru yang termotivasi secara intrinsik dalam proses pengajaran maka secara positif akan memengaruhi motivasi siswa. Namun disisi lain, guru yang rendah motivasi mengajarnya cenderung kurang terlibat dalam kegiatan sekolah, tidak menikmati kegiatan di sekolah, dan kurang terlibat dalam tugastugas belajar (Ntoumanis, Pensgaard, Martin \& Pipa, 2004; Perlman, 2013).

Studi tentang motivasi guru bahwa guru memilih profesi mengajar terdiri atas berbagai pertimbangan, diantaranya: (1) pertimbangan intrinsik yang berkaitan 
dengan kegiatan peran guru, seperti pengembangan pribadi dan keinginan untuk pertumbuhan pribadi, seperti halnya karir yang cocok untuk kehidupan keluarga (Williams \& Forgasz, 2009); (2) pertimbangan ekstrinsik yang berkaitan dengan aspek dalam mengajar, seperti kondisi kerja, keamanan kerja, dan status sosial (Richardson, Karabenick, \& Watt, 2014); (3) pertimbangan altruistik berkaitan dengan persepsi mengajar sebagai profesi dihormati secara sosial dan keinginan untuk bekerja dengan anak-anak, serta memberikan kontribusi kepada masyarakat (Mansfield, Wosnitza, \& Beltman 2012; Chong \& Low, 2009; Sharif, Hossan, \& McMinn, 2014; Ozturk, 2012).

Faktor yang mempengaruhi motivasi mengajar guru adalah berkaitan dengan kepuasan kebutuhan. Motivasi didorong melalui pemenuhan kebutuhan psikologis dasar. Menurut Gagne dan Deci (2005), kepuasan kebutuhan psikologis dasar merupakan nutriment untuk pengembangan motivasi. Kebutuhan psikologis dasar individu yang terdiri dari kompetensi, otonomi dan keterhubungan merupakan kebutuhan yang mendasar dan universal untuk kebahagiaan manusia.

Kepuasan kebutuhan penting untuk diteliti karena kepuasan tersebut menimbulkan berbagai konsekuensi positif, seperti kesehatan mental, kesehatan fisik, dan kinerja (Baard, Deci, \& Ryan, 2004; Deci, dkk, 2001). Konsekuensi penting lainnya dari kepuasan kebutuhan individu adalah motivasi intrinsik (Gagne \& Deci, 2005). Kepuasan kebutuhan berkaitan dengan kebutuhan dasar psikologis competence (kompetensi) atau achievement (prestasi), autonomy and control (otonomi dan kontrol) atau power (kekuasaan), dan relatedness (hubungan) atau affiliation (afiliasi) (Woolfolk, 2009).

Ketertarikan dan keinginan serta motivasi guru untuk mengajar akan muncul bila adanya pengalaman kepuasan kebutuhan secara psikologis dalam hal otonomi, kompetensi, dan keterkaitan selama terlibat aktivitas mengajar dan berinteraksi dengan siswa (Reeve \& Su, 2014). Selain itu, Arshadi (2010) dalam kajian penelitiannya tentang adanya pengaruh dukungan otonomi terhadap motivasi kerja dan prestasi kerja di mediasi need satisfaction. Temuan penelitian lain terkait kepuasan kebutuhan, juga disampaikan oleh Budiman, Matsum, dan Herkulana (2014), bahwa hal yang mendasari motivasi mengajar guru yaitu kesesuaian cita-cita dengan keinginan dasar menjadi guru, adanya kepuasan dalam mendidik dan mengajar yang menumbuhkan kerelaan menjadi guru, terutama guru tidak tetap.

Berdasarkan uraian di atas maka penelitian mengenai motivasi mengajar pada guru penting dilakukan dengan melibatkan faktor kepuasan kebutuhan. Kondisi dan fenomena di atas menginspirasi peneliti untuk meneliti motivasi mengajar guru ditinjau dari kepuasan kebutuhan dalam perspektif determinasi diri.

Tujuan penelitian ini adalah menganalisis motivasi mengajar guru ditinjau dari kepuasan kebutuhan dalam perspektif determinasi diri. Dengan kata lain, penelitian ini secara khusus bertujuan untuk menganalisis kontribusi kepuasan kebutuhan untuk mandiri, kepuasan kebutuhan untuk kompeten, dan kepuasan kebutuhan untuk terhubung dengan orang lain yang dikaitkan dengan motivasi mengajar guru.

\section{METODE}

\section{Partisipan Penelitian}

Subjek dalam penelitian ini adalah guru TK/RA di Kabupaten Kediri dan Kabupaten Tulungagung berjumlah 84 orang (100\% perempuan). Karakteristik partisipan penelitian ini sebagai berikut: (1) usia dewasa dengan rentangan 21-61 tahun; (2) guru TK/RA yang mengajar di Kabupaten Kediri dan Kabupaten Tulungagung dengan status perkembangan daerah terpencil. Total keseluruhan data satuan pendidikan TK/RA di Kabupaten Kediri dan Kabupaten 
Tulungagung berjumlah 1659; (3) memiliki masa kerja minimal 2 tahun, dengan pertimbangan bahwa dengan masa kerja tersebut guru mampu beradaptasi dengan lingkungan kerjanya.

\section{Instrumen Penelitian}

Kepuasan kebutuhan diukur dengan menggunakan skala Basic Need Satisfaction in General (Deci \& Ryan, 2000) yang mengungkap sejauh mana individu mengalami kepuasan atas tiga kebutuhan dasar yaitu kepuasan kebutuhan dasar untuk mandiri, terhubung dengan orang lain dan kompeten pada profesi individu tersebut. Kepuasan kebutuhan untuk mandiri mengacu pada rasa kemauan dan kebebasan psikologis (Ryan \& Deci, 2002; vansteenkiste, dkk, 2010); kepuasan kebutuhan untuk terhubung dengan orang lain mengacu pada perasaan memiliki kepada orang lain, dan untuk merawat dan dirawat orang lain (van de Berghe, dkk, 2014); dan kepuasan kebutuhan kompetensi melibatkan perasaan efektif dalam tindakan atau kegiatan individu.

Skala kepuasan kebutuhan ini memiliki rentang pilihan respon dari 1 hingga 7, yaitu, "Sangat Tidak Sesuai (STS), "Tidak Sesuai (TS), "Agak Tidak Sesuai (ATS), "Raguragu (R)", "Agak Sesuai (AS), "Sesuai (S), dan "Sangat Sesuai (SS)". Setiap aitem diberi skor, yaitu dimulai skor 1 untuk pilihan "sangat tidak sesuai" hingga skor 7 untuk pilihan "sangat sesuai" untuk aitem yang favourable. Namun, pemberian skor dibalik untuk aitem unfavourable, yaitu dimulai skor 1 untuk pilihan "sangat sesuai" hingga skor 7 untuk pilihan "sangat tidak sesuai".

Partisipan penelitian diminta untuk menunjukkan bagaimana perasaan dari setiap pernyataan dan menanggapi pernyataan pada pilihan respon, seperti, "saya sangat menyukai orang-orang yang bekerja sama dengan saya"; "Tidak banyak orang di tempat kerja yang dekat denganku"; "saya memiliki kebebasan untuk mengungkapkan ide dan pendapat di tempat kerja". Nilai koefisien reliabilitas skala dalam penelitian ini untuk kepuasan kebutuhan mandiri sebesar 0,93; koefisien reliabilitas kepuasan kebutuhan kompeten sebesar 0,74; dan koefisien reliabilitas kepuasan kebutuhan untuk terhubung dengan orang lain sebesar 0,82 .

Motivasi mengajar diukur dengan menggunakan kuesioner Autonomous Motivation for Teaching untuk mengukur motivasi mengajar guru. Alat ukur ini mengacu pada teori self determination yang dirancang khusus untuk mempelajari motivasi untuk mengajar dan terdiri atas empat tipe motivasi, yaitu motivasi eksternal, motivasi introyeksi, motivasi identifikasi, dan motivasi intrinsik.

Kuesioner ini terdiri atas 16 item dan memiliki rentang pilihan respon dari 1 hingga 5 , mulai dari "sangat tidak sesuai" hingga "sangat sesuai". Setiap pernyataan memiliki empat pilihan respon jawaban dalam bentuk skala likert dari angka 1 sampai angka 5. Angka 1 untuk "sangat tidak sesuai"; angka 2 untuk "tidak sesuai"; angka 3 untuk "agak sesuai"; dan angka 4 untuk "sesuai", serta angka 5 untuk "sangat sesuai" Setiap item diberi skor, dan kemudian skor dihitung. Skor motivasi yang dikendalikan (controlled motivation) didasarkan pada motivasi eksternal dan motivasi introyeksi, sedangkan skor motivasi untuk mandiri (autonomous motivation) didasarkan pada motivasi identifikasi dan motivasi intrinsik.

Partisipan penelitian diminta untuk menunjukkan bagaimana perasaan dari setiap pernyataan dan menanggapi pernyataan pada pilihan respon, seperti, "Saya akan merasa malu dengan diri saya sendiri bila tidak bekerja dengan sungguhsungguh"; "Ketika saya mencoba untuk menemukan topik yang menarik dan cara mengajar yang baru, saya melakukannya, karena penting bagi saya untuk mengikuti inovasi dalam pengajaran"; "Ketika saya mencoba mencari topik menarik dan cara mengajar yang baru, saya melakukannya 
karena saya senang menciptakan hal-hal baru". Nilai koefisien reliabilitas skala dalam penelitian ini sebesar 0,92.

\section{Prosedur Penerjemahan Instrumen Penelitian}

Peneliti menterjemahkan item dalam instrumen-instrumen penelitian dari Bahasa Inggris ke Bahasa Indonesia berdasarkan Guidelines for Translating and Adapting Tests (Second Edition) dari International Test Commision (2017) sebagai pedoman, dengan langkah-langkah sebagai berikut:

(a) melakukan perijinan penggunaan dan ketersediaan alat ukur asli;

(b) melakukan penterjemahan item berbahasa Inggris ke dalam bahasa Indonesia oleh dua orang yang mampu berbahasa Inggris;

(c) Dua orang yang memiliki kemampuan bahasa Indonesia yang baik namun tidak bisa berbahasa Inggris memeriksa apakah itemitem dalam kuesioner yang telah diterjemahkan dalam bahasa Indonesia mudah dipahami;

(d) Item berbahasa Indonesia diterjemahkan kembali dalam bahasa Inggris oleh dua orang bilingual yang tidak pernah membaca item tersebut sebelumnya;

(e) melakukan proses membandingkan dan memeriksa item hasil terjemahan bahasa Inggris dengan item versi asli yang berbahasa Inggris;

(f) Lima orang pembaca item, yaitu lima orang yang berprofesi sebagai guru Taman kanak-kanak mengecek keterbacaan itemitem dengan tujuan untuk mengetahui pemahaman awam terhadap pernyataan dari setiap item.

\section{Analisis Statistik}

Teknik analisis data dalam penelitian ini menggunakan teknik analisis statistik deskriptif dengan tujuan untuk melihat deskripsi secara umum partisipan. Di samping itu, untuk melihat signifikansi motivasi mengajar ditinjau dari kepuasan kebutuhan, maka digunakan teknik analisis Pearson Correlation.

\section{HASIL DAN PEMBAHASAN}

\section{Data Demografis Penyebaran Partisipan Penelitian}

Partisipan penelitian ini adalah Guru PAUD yang mengajar di Kabupaten Kediri dan Kabupaten Tulungagung yang berjumlah 84 orang yang semuanya berjenis kelamin perempuan. Karakteristik umum subjek penelitian dapat dilihat pada Tabel 1. Rentang usia subjek dimulai dari usia 21 tahun sampai usia 61 tahun. Sebagian besar subjek berusia antara 23-41 tahun dengan persentase 70,24 persen (rata-rata usia 31,71 tahun, $S D=8,86$ ), dan sebagian besar masa kerja subjek penelitian pada kisaran 2 - 12 tahun (rata-rata lama mengajar 6,37 tahun, $S D=5,38$ ) dengan persentase 90,47 persen.

Tingkat kepuasan kebutuhan menunjukkan bahwa bahwa mayoritas (82\%) subjek memiliki kepuasan kebutuhan untuk mandiri dalam kategori sedang. Selain itu, sebanyak 72 subjek atau sebesar 85,71 persen memiliki kepuasan kebutuhan untuk terhubung dengan orang lain dalam kategori sedang, begitu juga sebanyak 60 subjek atau sebesar 71,42 persen memiliki kepuasan kebutuhan dalam kategori sedang. Deskripsi tentang motivasi mengajar menunjukkan bahwa sebagian besar subjek penelitian memiliki nilai motivasi untuk mengajar berada pada kategori sedang dengan persentase 72,61 persen atau sebanyak 61 subjek. Kategorisasi tingkat kepuasan kebutuhan dan motivasi mengajar dapat dilihat pada Tabel 2.

Teknik statistik yang digunakan untuk melihat signifikansi motivasi mengajar ditinjau dari kepuasan kebutuhan, yaitu teknik Pearson Correlation. Tabel 3 memberikan hasil statistik deskriptif (ratarata dan standar deviasi) dan hasil perhitungan motivasi mengajar ditinjau dari kepuasan kebutuhan 
Tabel 1.

Karakteristik Umum Subjek Penelitian

\begin{tabular}{lccc}
\hline Karakteristik Subjek & Data Subjek & Frekuensi & Persentase\% \\
\hline Usia & $21-22$ tahun & 15 & 17,86 \\
& $23-41$ tahun & 59 & 70,24 \\
Lama Mengajar & $42-61$ tahun & 10 & 11,90 \\
& $2-12$ tahun & 76 & 90,47 \\
& $13-33$ tahun & 8 & 9,52 \\
\hline
\end{tabular}

Tabel 2.

Kategorisasi Tingkat Variabel

\begin{tabular}{ccccc}
\hline Konstrak & Tingkat & Skor & Frekuensi & Persentase\% \\
\hline Kepuasan Kebutuhan untuk Mandiri & Rendah & $19-26$ & 10 & 11,90 \\
& Sedang & $27-35$ & 69 & 82,14 \\
& Tinggi & $36-40$ & 5 & 5,95 \\
Kepuasan Kebutuhan untuk Terhubung & Rendah & $13-41$ & 9 & 10,71 \\
dengan orang lain & Sedang & $42-54$ & 72 & 85,71 \\
& Tinggi & $55-56$ & 3 & 3,57 \\
Kepuasan Kebutuhan untuk Kompeten & Rendah & $12-24$ & 13 & 15,47 \\
& Sedang & $25-36$ & 60 & 71,42 \\
& Tinggi & $37-40$ & 11 & 13,09 \\
Motivasi Mengajar & Rendah & $49-54$ & 12 & 14,28 \\
& Sedang & $55-67$ & 61 & 72,61 \\
& Tinggi & $68-77$ & 11 & 13,09 \\
\hline
\end{tabular}

Tabel 3.

Hasil Perhitungan Motivasi Mengajar Ditinjau dari Kepuasan Kebutuhan

\begin{tabular}{lccll}
\hline \multicolumn{1}{c}{ Variabel } & M & SD & $\boldsymbol{r}$ & Sig $(\boldsymbol{p})$ \\
\hline 1. Kepuasan Kebutuhan untuk Mandiri & 31,27 & 3,778 & 0,043 & 0,585 \\
2. Kepuasan Kebutuhan untuk Terhubung dengan orang lain & 48,32 & 6,070 & $0,208^{* *}$ & $0,008^{* *}$ \\
3. Kepuasan Kebutuhan untuk Kompeten & 30,74 & 5,330 & $0,167^{*}$ & $0,031^{*}$ \\
4. Motivasi Mengajar & 61,21 & 6,078 & - & \\
\hline
\end{tabular}

$p<0,05, * * p<0,01 ; \mathrm{M}=$ Mean; $\mathrm{SD}=$ Standar Deviasi

Berdasarkan data pada tabel di atas hasil perhitungan kepuasan kebutuhan untuk mandiri dengan motivasi mengajar guru menunjukkan hasil yang tidak signifikan, yaitu nilai korelasi sebesar 0,043 dan nilai $p$ $=0,585$. Hasil tersebut menyatakan kepuasan kebutuhan untuk mandiri tidak memiliki korelasi pada motivasi mengajar guru, dan perubahan skor pada kepuasan kebutuhan untuk mandiri tidak menyebabkan perubahan skor pada motivasi guru untuk mengajar. Hasil perhitungan kepuasan kebutuhan untuk terhubung dengan orang lain dengan motivasi mengajar guru menunjukkan hasil yang signifikan, yaitu nilai korelasi sebesar 0,208 dan nilai $p=0,008(p<0,01)$. Hasil tersebut memiliki nilai dan arah positif, yang dalam hal ini memiliki arti bahwa semakin tinggi skor kepuasan kebutuhan untuk terhubung dengan orang lain, maka semakin tinggi skor motivasi guru untuk mengajar. Hasil perhitungan kepuasan kebutuhan untuk kompeten dengan motivasi mengajar guru menunjukkan hasil yang signifikan, yaitu nilai korelasi sebesar 0,167 dan nilai $p=$ $0,031(p<0,05)$. Hasil tersebut memiliki nilai dan arah positif, yang dalam hal ini memiliki arti bahwa semakin tinggi skor 
kepuasan kebutuhan untuk kompeten, maka semakin tinggi skor motivasi guru untuk mengajar.

Motivasi dengan menggunakan teori determinan diri atau dikenal istilahnya dengan motivasi determinasi diri merupakan motivasi dari dalam individu yang memberikan dorongan terbesar untuk individu berperilaku (Gagne \& Deci, 2005; Deci \& Ryan, 2008). Motivasi dengan menggunakan teori determinan diri menjadi fokus berbagai penelitian karena dorongan ini memberikan kontribusi yang besar untuk organisasi. Individu berperilaku berdasarkan kemauan dirinya sendiri, sukarela tanpa adanya perasaan tertekan, terpaksa dan keharusan untuk melakukan tindakannya. Motivasi determinan diri didorong melalui pemenuhan kebutuhan psikologis dasar. Menurut Gagne dan Deci (2005), kepuasan kebutuhan psikologis dasar merupakan nutriment untuk pengembangan motivasi determinan diri. Kebutuhan psikologis dasar individu yang terdiri dari rasa kompetensi, otonomi dan keterhubungan merupakan kebutuhan yang mendasar dan universal untuk kebahagiaan manusia. Pengalaman kepuasan kebutuhan berdasarkan teori determinasi diri merupakan kekuatan pendorong dari kualitas motivasi. Teori kebutuhan psikologis dasar, salah satu di teori determinasi diri (vansteenkiste, Niemiec, \& Soenens, 2010), menyatakan bahwa bentuk kepuasan dari tiga kebutuhan psikologis dasar untuk mandiri, kompetensi dan keterhubungan diperlukan untuk mengembangkan motivasi otonom.

Konteks yang mendukung kepuasan kebutuhan kemandirian individu adalah mengacu pada rasa kemauan dan kebebasan psikologis (Ryan \& Deci, 2002; vansteenkiste, Niemic, \& Soenens, 2010). Di dalam konteks sekolah, ketika guru memiliki kepuasan kebutuhan psikologis dasar untuk mandiri, guru merasa diizinkan untuk mengekspresikan ide-ide dan opini, muncul kapasitas diri yang otentik, dan guru bebas untuk melakukan hal-hal dengan cara guru sendiri. Hal tersebut senada dengan kajian yang dilakukan oleh Meyer dan Maltin (2010) yang menjelaskan bahwa kepuasan kebutuhan untuk mandiri terjadi ketika pada tingkat terdalam dari refleksi, individu percaya bahwa apa yang mereka lakukan adalah dipilih secara bebas dan konsisten dengan nilai-nilai inti mereka. Namun, berdasarkan hasil penelitian ini menyatakan bahwa kepuasan kebutuhan untuk mandiri tidak berpengaruh pada motivasi mengajar guru. Hal ini berarti bahwa perubahan pada kepuasan kebutuhan untuk mandiri tidak menyebabkan perubahan pada motivasi guru untuk mengajar. Guru dengan kepuasan kebutuhan kemandirian tinggi tidak serta merta memiliki motivasi mengajar tinggi, dan sebaliknya guru dengan kepuasan kebutuhan kemandirian rendah tidak serta merta memiliki motivasi mengajar yang rendah. Hasil penelitian Lapointe (2006) dengan menggunakan pedoman wawancara sebagai instrumen penelitiannya, menyatakan bahwa guru yang memiliki kepuasan kebutuhan tinggi atau rendah ternyata memiliki banyak kesamaan dan relatif sedikit perbedaan dalam memberikan persepsi tentang lingkungan sekolah dan lingkungan kelas.

Selanjutnya, kepuasan kebutuhan kompetensi melibatkan perasaan efektif dalam tindakan atau kegiatan individu. Kepuasan kebutuhan untuk kompeten terjadi ketika individu percaya bahwa mereka memiliki kemampuan dan sumber daya yang dibutuhkan untuk menyelesaikan tugastugasnya dan mencapai tujuan. Guru akan merasa kompeten di tempat kerja ketika guru merasa mampu untuk menjalankan pekerjaan dengan baik dan ketika guru dapat menyelesaikan tugas-tugas yang menantang (van den Broeck, dkk, 2010). Hal ini juga sesuai dengan hasil penelitian ini bahwa kepuasan kebutuhan untuk kompeten berpengaruh terhadap mengajar guru. Hal ini memiliki arti bahwa semakin tinggi skor kepuasan kebutuhan untuk kompeten, maka semakin tinggi motivasi guru untuk mengajar. 
Hasil penelitian ini menunjukkan bahwa kepuasan kebutuhan untuk terhubung dengan orang lain berpengaruh terhadap motivasi mengajar guru. Hal ini terjadi karena kepuasan kebutuhan guru untuk terhubung dengan orang lain mengacu pada perasaan belongingness kepada orang lain, dan untuk merawat dan dirawat orang lain (Baumeister \& Leary, dikutip van de Berghe, dkk, 2014). Hal ini sejalan juga dengan hasil penelitian van de Berghe, dkk, (2014) yang menyatakan bahwa kebutuhan untuk terhubung ini akan puas ketika guru merasa terhubung dengan rekan-rekan sejawat, dan orang lain dalam lingkungan kerja (misalnya, kepala sekolah, siswa, dan orang tua). Selain itu, menurut kajian Baard, Deci, dan Ryan (2004), kepuasan kebutuhan yang dialami guru adalah ketika guru lebih menyukai sepenuhnya untuk menerima strategi pengajaran yang diusulkan (kepuasan kebutuhan untuk mandiri), guru merasa percaya diri untuk menyelesaikan tugas, memberikan arahan secara tidak langsung, dan diberi kesempatan untuk berbicara selama pelatihan profesional guru (kepuasan kebutuhan untuk kompeten), dan guru merasa terhubung dengan orang lain selama pelatihan profesional guru (kepuasan kebutuhan untuk terhubung dengan orang lain).

Implikasi hasil penelitian ini adalah karena semua guru yang berpartisipasi dalam penelitian ini semuanya wanita, maka penting untuk mereplikasi temuan ini juga dengan guru pria. Selain itu, saran untuk peneliti selanjutnya supaya dapat menggunakan desain longitudinal dengan pengukuran berulang sepanjang waktu. Desain ini dapat meningkatkan kemampuan peneliti untuk menarik kesimpulan kausal, tentu saja dalam batas riset noneksperimental.

\section{SIMPULAN}

Hasil penelitian menunjukkan bahwa kepuasan kebutuhan untuk mandiri tidak berpengaruh pada motivasi mengajar guru, namun kepuasan kebutuhan untuk terhubung dengan orang lain dan kepuasan kebutuhan untuk kompeten berpengaruh positif terhadap motivasi mengajar guru. Pemahaman akan kajian mengenai motivasi mengajar berdasar determinasi diri, diharapkan dapat membantu guru, khususnya di daerah terpencil, untuk meningkatkan dan mengenal potensi diri, sehingga guru dapat mengembangkan diri dengan mengoptimalkan kepuasan kebutuhan sebagai faktor yang berpengaruh pada aktivitas guru dalam mengajar.

\section{UCAPAN TERIMA KASIH}

Terima kasih diucapkan pada Lembaga Penelitian dan Pengabdian Pada Masyarakat Universitas Nusantara PGRI Kediri sebagai pemberi dana hibah penelitian. Ucapan terima kasih juga disampaikan kepada Ketua Program Studi S3 Fakultas Psikologi Universitas Airlangga atas dukungan yang diberikan pada peneliti.

\section{DAFTAR PUSTAKA}

Arshadi, N. (2010). Basic need satisfaction, work motivation, and job performance in an industrial company in iran. Procedia Sosial and Behavioural Sciences, 5, 1267-1272

Baard, P. P., Deci, E. L., \& Ryan, R. M. (2004). Intrinsic need satisfaction: a motivational basis of performance and well being in two work setting. Journal of Applied Social Psychology, 34(10), 2045-2068

Baswedan, A. R. (2014). Gawat darurat pendidikan di Indonesia. Makalah dipresentasikan dalam acara

Silaturahmi Kementrian dengan Kepala Dinas. Jakarta: Kemendikbud.

Bernaus, M., \& Gardner, R. C. (2008). Teacher motivation strategies, student perceptions, student motivation, and english achievement. The Modern Language Journal, 92, 387-401. 
Bernaus, M., Wilson, A., \& Gardner, R. C. (2009). Teacher's motivation, classroom strategy use, student's motivation and second language achievement. Porta Linguarum, 12, 25-36

Black, A. E., \& Deci, E. L. (2000). The effects of instructors' autonomy support and students' autonomous motivation on learning organic chemistry: A self determination theory perspective. Science Education, 84(6), 740-756

Bieg, S., Backes, S., \& Mittag, W. (2011). The role of intrinsic motivation for teaching, teachers' care and autonomy support in students' self-determined motivation. Journal for Educational Research Online, 3(1), 122-140

Budiman, J., Matsum, J., \& Herkulana. (2014). Analisis motivasi dan komitmen mengajar guru tidak tetap berbasis kompensasi di kecamatan Meliau kabupaten Sanggau. Jurnal Pendidikan dan Pembelajaran, 3(8), 113.

Carson, R. L., \& Chase, M. A. (2009). An examination of physical education teacher motivation from a selfdetermination theoretical framework. Physical Education and Sport Pedagogy, 14, 335-353

Chong S., \& Low, E. L. (2009). Why i want to teach and how i feel about teachingformation of teacher identity from preservice to the beginning teacher phase. Educational Research Policy and Practice, 8, 59-72.

Deci, E. L., \& Ryan, R. M. (2000). The 'what' and 'why' of goal pursuits: human needs and the self determination of behavior. Psychological Inquiry, 11, 227-268
Deci, E. L., \& Ryan, R. M. (2002). Selfdetermination research: Reflections and future directions. In E. L. Deci \& R. M. Ryan (Eds.), Handbook of SelfDetermination Research (pp. 431442). Rochester, NY: University of Rochester Press.

Deci, E. L. \& Ryan, R. M. (2008). Selfdetermination theory: a macrotheory of human motivation, development, and health. Canadian Psychology, 49(3), 182-185

Deci, E. L., Ryan, R. M., Gagné, M., Leone, D., Usunov, J., \& Kornazheva, B. P. (2001). Need satisfaction, motivation, and well-being in the work organizations of a former Eastern Bloc Country. Personality and Social Psychology Bulletin, 27, 930-942

Dinham, S., \& Scott, C. (2000). Moving into the third, outer domain of teacher satisfaction. Journal of Educational Administration, 38, 379-396

Direktorat Pembinaan Paud. (2012). Petunjuk teknis bantuan penyelenggaraan rintisan PAUD di daerah terpencil dan perbatasan. Jakarta: Kemendikbud DirjeN PAUDNI

Ditjen PDT. (2016). Daftar daerah tertinggal berdasarkan indeks IPD dan kategori desa. Diakses pada tanggal 9 Mei 2017 dari

http://datin.kemendesa.go.id/pusdatin/s impora1/

report_tertinggal_ipdsmry.php

Gagne, M. (2003). The role of autonomy support and autonomy orientation in prosocial behavior engagement. Motivation and Emotion, 27, 199-223

Gagne, M., \& Deci, E. L. (2005). Selfdetermination theory and work motivation. Journal of Organizational Behavior, 26, 331-362. 
Gagne, M., \& Deci, E.L. (eds.). (2014). The oxford handbook of work engagement, motivation, and self-determination theory. New York: Oxford University Press

Hamidi, H., Endang, B., \& Chiar, M. (2015). Motivasi guru bertahan mengajar di daerah terpencil. Jurnal Pendidikan dan Pembelajaran, 4(3)

Han, J., Yin, H., \& Wang, W. (2015). Exploring the relationship between goal orientations for teaching of tertiary teachers and their teaching approaches in china. Asia Pacific Education Review, 16, 1-11

Han, J., Yin, H., \& Wang, W. (2016). The effect of tertiary teachers' goal orientations for teaching on their commitment: The mediating role of teacher engagement. Educational Psychology, 36, 526-547

Hein, V., Ries, F., Pires, F., Caune, A., Heszteráné Ekler, J., Emeljanovas, A., \& Valantiniene, I. (2012). The relationship between teaching styles and motivation to teach among physical education teachers. Journal of Sports Science \& Medicine, 11(1), 123-130

Howard, S., \& Johnshon, B. (2004). Resilient teachers: resisting stress and burnout. Social Psychology of Education, 7, 399-420

International Test Commission (2017). ITC guidelines for translating and adapting tests (second edition). International Journal of Testing, 18(2), 101-134

Jesus, S. N., \& Lens, W. (2005). An integrated model for the study of teacher motivation. Applied Psychology: An International Review, 54(1), 119-134.

Kadir, D. (2015, Januari). Nelangsa Guru antara Terpencil dan Tidak Terpencil. Kompasiana (on-line). Diakses tanggal $01 \quad$ Februari 2016 dari http://www.kompasiana.com/lawise/ nelangsa-guru-antara-terpencil-dan tidak terpencil_550bbcfc813311e078b1e734

Kemdikbud. (2016). Jumlah data satuan pendidikan (sekolah) anak usia dini per provinsi. Data referensi Kementrian Pendidikan dan Kebudayaan (on-line). Diakses tanggal 2 November 2016 dari http://referensi.data.kemdikbud.go.id/ index21.php

Kiziltepe, Z. (2008). Motivation and demotivation of university teachers. Teachers and Teaching, 14, 515-530

LaPointe, L. (2006). The relationships between teacher need satisfaction and perceptions of school and classroom environments. (Electronic Thesis or Dissertation). Retrieved from https://search.proquest.com/

Levesque, M., Blais, M. R., \& Hess, U. (2004). Motivational dynamic of burnout and well-being among african teachers. Canadian Journal of Behavioural Science, 36(3), 190-201

Mansfield, C., Wosnitza, M., \& Beltman, S. (2012). Goals for teaching: towards a framework for examining motivation of graduating teachers. Australian

Journal of Educational \& Developmental Psychology, 12, 21-34

Meyer, J. P., \& Maltin, E. R. (2010). Employee commitment and wellbeing: A critical review, theoritical framework and research agenda. Journal of Vocational Behavior, 77, 323-377.

Ntoumanis, N., Pensgaard, A.M., Martin, C., \& Pipa, K. (2004). An idiographic analysis of amotivation in compulsory school physical education. Journal of 
Sport \& Exercise Psychology, 26, 197214

Ozturk, A. E. (2012). Motivations of Turkish pre-service teachers to choose teaching as a career. Australian Journal of Teacher Education, 37(10)

Paramitha, P. P. (2012). Resiliensi guru di sekolah terpencil. Jurnal Psikologi Pendidikan dan Perkembangan, 1(02), 1-6

Perlman, D. J. (2011). The influence of an autonomy-supportive intervention on preservice teacher instruction: a selfdetermined perspective. Australian Journal of Teacher Education. 36(11), Article 6

Retelsdorf, J., \& Gunther, C. (2011). Achievement goals for teaching and teachers' reference norms: relations with instructional practices. Teaching and Teacher Education, 27, 11111119

Reeve, J., \& Su, Y. L. (2014). Teacher motivation. In M. Gagne' (Ed.), The Oxford handbook of workplace motivation (Chpt. 21, pp. 349-362). New York: Oxford University Press.

Richardson, P. W., Karabenick, S. A., \& Watt, H. M. G. (eds.). (2014). Teacher motivation: Theory and practice. New York: Routledge

Roth, G., Assor, A., Kanat-Maymon, Y. \& Kaplan, H. (2007). Autonomous motivation for teaching: how selfdetermined teaching may lead to selfdetermined learning. Journal of Educational Psychology, 99(4), 761774

Ryan, R. M., \& Deci, E. L. (2002). An overview of Self-determination Theory: An organismic-dialectical perspective. In E. L. Deci \& R. M. Ryan (Eds.), Handbook of selfdetermination research.3-33.
Rochester, NY: The University of Rochester Press.

Ryan, R. M., \& Deci, E. L. (2009). Promoting self-determined school engagement : Motivation, Learning, and Well-Being. In K. R. Wentzel \&

A. Wigfield (Eds.), Handbook of Motivation at School (pp. 171-196).

New York: Routledge

Shen, Bo., McCaughtry, N., Martin, J., \& Fahlman, M. (2009). Effects of teacher autonomy support and students' autonomous motivation on learning in physical education. The American Alliance for Health, Physical Education, Recreation and Dance, 80(1), 44-53

Snowman, J., McCown, R, \& Biehler, R. (2012). Psychology applied to teaching (13thed.). Belmont, CA: Wadesworth, Cengage Learning.

Sinclair, C. (2008). Initial and changing student teacher motivation and commitment to teaching. Asia-Pacific Journal of Teacher Education, 36, 79104

Sharif, T., Hossan, C. G. \& McMinn, M. (2014). Motivation and determination of intention to become teacher: A case of B. Ed. students in UAE. International Journal of Business and Management, 9(5), 60-73.

Sugino, T. (2010). Teacher demotivational factors in the japanese language teaching context. Procedia-Social and Behavioral Sciences, 3, 216-226

Thoonen, E. E. J., Sleegers, P. J. C., Oort, F. J., Peetsma, T. T. D., \& Geijsel, F. P. (2011). How to improve teaching practices: The role of teacher motivation, organizational factors, and leadership practices. Educational Administration Quarterly, 47, 496-536 
Tim Litbang. (2016). Kecukupan guru masih semu, beban para guru di daerah tertinggal sangat berat. Kompas (online). Diakses tanggal 2 November 2016

dari https://www.pressreader.com/.../kompa s/20161121/281479276007...

van de Berghe, L., Soenens, B., Aelterman, N., Cardon, G., Tallir, I. B., \& Haerens, L. (2014). Within-person profiles of teachers' motivation to teach: Associations with need satisfaction at work, need-supportive teaching, and burnout. Psychology of Sport and Exercise, 15, 407- 417

van den Broeck, A., Vansteenkiste, M., de Witte, H., Soenens, B., \& Lens, W.

(2010). Capturing autonomy, competence, and relatedness at work: Construction and initial validation of the work-related basic need satisfaction scale. Journal of Occupational and
Organizational Psychology, 83(4), 981-1002

vansteenkiste, M., Niemiec, C. P., \& Soenens, B. (2010). The development of the five mini-theories of selfdetermination theory: An historical overview, emerging trends, and future directions. The Decade Ahead: Theoretical Perspectives on Motivation and Achievement Advances in Motivation and Achievement, 16A, 105-165

Williams, J., \& Forgasz, H. (2009). The motivations of career change students in teacher education. Asia-Pacific Journal of Teacher Education, 37(1), 95-108.

Woolfolk, A. (2009). Educational psychology active learning edition. (Helly P.S, Trans). Yogyakarta: Pustaka Pelajar 